\title{
СТОЛКНОВЕНИЕ ЦИВИЛИЗАЦИЙ
}

\author{
В.В. Карякин
}

\section{ЦИВИЛИЗАЦИОННАЯ АНТРОПОЛОГИЯ АМЕРИКАНСКОГО ЭКСПАНСИОНИЗМА: ОТ ДОКТРИНЫ МОНРО К ГЛОБАЛЬНОМУ ЛИДЕРСТВУ}

\begin{abstract}
Аннотация. Современный внешнеполитический курс Соединённых Штатов на сохранение мирового лидерства, проводимый под лозунгом «партнёрства во имя мира» и реализуемый в форме расширения глобальных функций Североатлантического альянса, полностью вписывается в концепцию цивилизационной антропологии, которая изучает вопросы развития цивилизаций и крупных государственных образований на основе динамики мотиваций элит и других значимых общественных групп социума. В XX столетии Соединённые Штаты трижды принимали участие в конфронтационном противостоянии международных систем. Сюда можно отнести две мировые войны и одну "холодную», главным итогом которых было последовательное возрастание роли США на мировой арене. В течение одного столетия "Америка превратилась из страны, изолированной в Западном полушарии, в державу мирового масштаба по размаху интересов и влияния». Это привело к тому, что «ни одна значительная проблема не может быть сегодня решена без участия США или их активного противодействия».
\end{abstract}

Ключевые слова: международные отношения, внешняя политика, США, геополитика, политическая нестабильность, дипломатия, государство, интересы, ценности, безопасность.

$\mathrm{B}$ XX столетии Соединённые Штаты трижды принимали участие в конфронтационном противостоянии международных систем. Сюда можно отнести две мировые войны и одну "холодную», главным итогом которых было последовательное возрастание роли США на мировой арене. В течение одного столетия «Америка превратилась из страны, изолированной в Западном полушарии, в державу мирового масштаба по размаху интересов и влияния» ${ }^{1}$. Это привело к тому, что «ни одна значительная проблема не может быть сегодня решена без участия США или их активного противодействия»².

С момента опубликования Доктрины Монро в 1823 г. и по настоящее время Соединённые Штаты оказывают возрастающее влияние на формирование мирового порядка, в котором они остаются единственной сверхдержавой, сохраняющей лидирующее положение в мире.

Вместе с тем ввиду обостряющейся конкуренции за место на мировом Олимпе Соединённым Штатам всё труднее сохранить своё лидирующее положение. Нарождающиеся центры силы ставят под сомнение незыбле-

\footnotetext{
Бжезинский 36. Великая шахматная доска. Господство Америки и его геополитические императивы. М., 1999. С. 13.

2 Давыдов Ю.П. Расширение зоны ответственности атлантического мира // США - Канада: экономика, политика, культура. № 3. 2000. С. 17.
}

мость мирового порядка по американскому образцу, что актуализирует вопрос исследования истоков и движущих сил американского лидерства в плане перспектив его удержания и требований к претендентам на данное почётное место в мировой иерархии. В связи с этим правомерна постановка вопроса о путях трансформации мирового порядка, основанного на принципе американоцентризма - "e pluribus unum" (лат. - «из одной части»), к миру, к модели, построенной на основе полицентризма “e pluribus partium" (лат. - «из многих частей»), или же к какой-либо другой модели монополярности? При кажущемся коренном различии «однополярного» проекта от «многополярного» оба они, в сущности, близки друг другу, так как действуют в рамках одной парадигмы, означающей противостояние сил на международной арене на основе принципа: «один против всех».

Но в динамике современной глобализации прослеживается и другая тенденция, связанная с процессами глокализации ${ }^{3}$, которые можно охарактеризо-

\footnotetext{
Глокализация - это диалектический процесс взаимодействия локального и глобального, это не только замещение локальных процессов глобальными, но и выход локальных процессов на глобальный уровень (т.е их глобализация). В основе глокализации лежит идея децентрализованного и справедливого мира, ускорение мирового развития через развитие регионов и повышения внимания к локальным проблемам.
} 


\section{Международные отношения International Relations}

вать латинской максимой "е pluribus pluribum" (лат. "множественное во множественном»). Но это уже не тот многополярный мир, об устройстве которого ведётся дискуссия в политологических кругах, а мир глубоко фрагментированный благодаря росту конфликтогенности и социальной энтропии ${ }^{4}$, распространению социальных войн ${ }^{5}$ и применению технологий «управляемого хаоса» ${ }^{6}$ для дестабилизации социально-политической обстановки в отдельных странах. На первый взгляд данная модель мироустройства совершенно не вписывается в американскую концепцию удержания лидерства. Но это не так. Ситуация «управляемого хаоса» позволяет Америке реализовать на практике древний римский принцип: «разделяй и властвуй», который был взят на вооружение в последние десятилетия, когда стало ясно, что война - это слишком дорогое "удовольствие», сопровождающееся уничтожением ценных природных и людских ресурсов.

На этапе пути к глобальному лидерству Америка всегда делала ставку на силовое решение международных проблем. Недаром немецкий учёный К. Шмит писал, что «в 1898 г. США начали войну с Испанией, а затем и против всего мира, и конца этой войне не видно» ${ }^{7}$.

Культ силы, доктрина предопределённой судьбы американского народа, воплотившиеся в геополитических концепциях Х. Маккиндера, адмирала А.Т. Мэхэна, Н. Спайкмена, в доктрине Монро, универсализме В. Вильсона, и которые были отожествлены с интересами всего человечества - вот составляющие элементы идеологии мирового господства США, сложившиеся на рубеже XIX-XX вв. и с тех пор не претерпевшие значительных изменений.

Если обратиться к истории, то эра американского экспансионизма началась с публикации доктрины Монро и была положена в основу внешней политики

\footnotetext{
4 Энтропия социальная - мера отклонения социальной системы или её отдельного элемента от принятого как эталонное (нормальное, ожидаемое) состояние, проявляющееся в снижении уровня организации, эффективности функционирования, направлением и темпов развития государства.

Социальная война - характеристика современного общества, находящегося в зоне бифуркации. Отличается от классической гражданской войны вырождением в массовые социальные девиации - преступность, алкоголизм, наркоманию, нищету, отказ от общественно полезного труда.

6 «Управляемый хаос» - концепция американского политолога С. Манна, целью которой является создание условий, при которых утрачиваются национальная идентификация, культурные и конфессиональные ценности социума, а его моральные нормы и традиционный общественный уклад подвергаются эрозии, упадку и разрушению.

Carl Schmitt. Der Nomos der Erde im Volkerrecht des jus publicum Europaeum. Cologne, 1950.
}

США на протяжении всего XX в., завершившегося развалом СССР и установлением контроля над странами Восточной Европы путём их присоединения к НАТО и расчленением Югославии.

Успех стран Запада в “холодной войне» против СССР и его союзников был закреплён в новой редакции доктрины Монро, получившей название доктрина Клинтона-Олбрайт, согласно которой НАТО присвоило себе глобальную ответственность за международную безопасность, стремясь потеснить ООН на международной арене. Таким образом, модифицированная доктрина Монро превратилась в инструмент завоевания геополитических пространств с целью реализации экспансионистских устремлений Соединённых Штатов для создания Большого пространства американской гегемонии не только в Западном полушарии, но и на Ближнем и Среднем Востоке.

А начало этому было положено формированием геополитической концепции универсализма, изложенной президентом США В. Вильсоном на Парижской мирной конференции, состоявшейся вскоре после окончания Первой мировой войны и завершившейся подписанием Версальского мирного договора в 1918 г. В это время усилия Вашингтона были направлены на превращение только что созданной Лиги Наций в инструмент установления англо-саксонского мирового господства путём включения, по требованию Вильсона, положений доктрины Монро в устав данной организации. Это был рубеж, после которого доктрина Монро покинула территорию Западного полушария и начала распространяться в Европе и Азии, превращаясь из инструмента американской региональной политики в доктрину мирового господства.

По этому поводу А.Л. Ловелл писал, что «мы не должны забывать о том, что экспансионизм - есть сущность англо-саксонской расы. Отказаться от экспансионизма было бы предательством. Экспансионизм является законом природы. Наша нация не будет в состоянии выжить, если она не будет подчиняться этому закону ${ }^{8}$. Из сказанного им можно сделать заключение о том, что экспансионизм является естественным императивом США. По убеждению американской политической элиты, исходя из расового превосходства англо-саксов, Соединённым Штатам суждено победить в борьбе за мировую гегемонию 9 .

Официальная американская пропаганда уже в начале XX столетия отличалась крайней демагогией. Войны за захват Кубы, Филиппинских и Гавайских

\footnotetext{
Lowell L.A. The Colonial Expansion of the United States. // Atlantic Monthly, LXXXII, 1999, pp. 145-154.

9 Hofstadter R. Social Darvinism in American Thought. Baecon Press, Boston, 1983, pp. 187-188.
} 


\section{Столкновение цивилизаций /}

Clash of civilizations

островов, а также Пуэрто-Рико, т.е. первые войны США за передел мира, изображались как «освободительные» и направленные на защиту населения данных стран от иностранного гнёта. При этом в американской пропаганде широко использовалась подмена понятия «агрессия» на такие понятия, как «защита» и «опека».

Американский президент Т. Рузвельт в своей политической деятельности придерживался откровенных милитаристских установок. В своей книге «Завоевание Запада» он писал: «никакой триумф мира не является столь великим, как высший триумф войны». Здесь же он отмечает, что завоевание "дикого Запада» белыми поселенцами является расовой войной между англосаксами и индейцами, и эта война была по воле судьбы «доведена до логического, с точки зрения расового социал-дарвинизма, конца ${ }^{10}$.

В послании Т. Рузвельта Конгрессу США 6 декабря 1904 г. говорилось: «Хронические правонарушения или бессилие, приводящее к распаду всех устоев цивилизации, могут, в конце концов, привести к необходимости интервенции цивилизованных стран, заставляет их выполнить обязанность международной полицейской силы» ${ }^{11}$

Детерминировали данную идею во времена правления администрации В. Вильсона Дж. Левин и Н. Гордон, которые утверждали, что «народы, отделившиеся после распада России, Австро-Венгрии и Турции, в своём подавляющем большинстве совершенно необразованные. Большинство из них или не в состоянии управлять собою или проявляют явную недостаточность в силе самоуправления. Эти народы потребуют долговременного ухаживания и воспитания для достижения экономической и политической самостоятельности ${ }^{12}$.

Исследователи американской политической мысли писали, что экономический империализм Т. Рузвельта, выраженный в политике "открытых дверей», является той же войной, но с применением других средств, которые в наше время облечены в форму стратегий «мягкой силы» и «непрямых действий». «Война - это экстремальная кульминация экономического соперничества между странами. Это означает, что международное экономическое соперничество, осуществляемое с целью завоевания новых рынков, должно неизбежно закончится войной. Вся предыдущая история является

10 Preface by Hart A.B. to the Works of Theodore Roosevelt. Charles Scribner's Sons, N.Y. , 1926.

11 Дипломатический словарь. Т. 1. Госполитиздат. М.: 1948. C. 272.

12 Levin Jr., Gordon N. Woodrow Wilson and World Politics. Oxford University Press, Oxford, 1968, p. 186. подтверждением этого неоспоримого факта. Политика «открытых дверей» должна вестись безмилостно и беспощадно» ${ }^{13}$.

Подтверждение этому мы можем найти в другом источнике, в котором политика «открытых дверей» характеризуется как «полное экономическое проникновение, имеющее то же эффект, что и территориальная оккупация» ${ }^{14}$.

Ещё в начале XX в. американский историк Б. Адамс в своих трудах предвосхитил начало «холодной войны». Он пришел к выводу, что планы установления американского мирового господства, которые подразумевают гегемонию и контроль над евразийским континентом, неминуемо приведут к конфликту с Россией. В своей статье «Новая индустриальная революция» он пишет, что «американцы должны понять, что это будет война не на жизнь, а на смерть. Это будет война не против отдельной нации, а против целого континента. В мире нет места двум империям. Один организм должен победить и уничтожить другой. Слабый организм должен погибнуть» ${ }^{15}$.

Таким образом, можно утверждать, что статья Б. Адамса явилась первым стратегическим документом не только планирования будущей «холодной войны», но и всей последующей политики Вашингтона на евразийском пространстве.

После окончания Первой мировой войны американские доктрины «Предопределённой судьбы», Монро и «Открытых дверей» слились воедино в Вильсоновском универсализме. В. Вильсон не только придал им глобальный характер, но и представил их предначертанными по воле Бога. Более того, он договорился даже до того, что сравнил себя если не с Богом, то, по крайней мере, с его сыном.

«Почему, - вопрошал Вильсон, - Иисус Христос не добился того, чтобы мир уверовал в его учение? Потому, что он ограничился проповедью идеалов, но не указал практических средств для их достижения. Я предлагаю осуществимый план доведения до конца стремления Христа» ${ }^{16}$.

Следуя идеологическим шаблонам своей доктрины, загримированных под «универсальные интересы человечества», Вильсон определил назначение Лиги

13 Williams A. The Shaping of American Diplomacy. Rand NcNally Company, Chicago, 1972, p. 423.

14 Поздняков Э.А. Геополитика. Изд. гр. «Прогресс-Культуpa». M.: 1995. C. 36.

15 Adams B. The New Industrial Revolution. Atlantic Monthly, LXXXVII, 1901, p. 165.

16 George D.L. The Truth About Peace Treaties. Vol. 1, London, 1938, pp. 223-225; Bailey T.A. A Diplomatic History of the American People. Prentice Hall Inc., Englewood Cliffs, 1980, p. 608. 


\section{Международные отношения International Relations}

Наций, которая должна была стать инструментом для создания американского мира. Он провозгласил: «Нам нужно решить единственный вопрос: вправе ли мы отказаться от руководства, примем ли мы или отвергнем доверие мира. Всё готово. Перст судьбы указывает нам путь. Это случилось не по плану, составленному человеческими руками. Нас ведёт бог. Мы не можем отступить. Мы можем лишь следовать вперёд со взором, устремлённым к небесам и с бодрым духом. Америке суждено указать истинный путь ${ }^{17}$.

В 1914 г. В. Вильсон заявил, что «США стремятся зажечь свет, которого мир никогда прежде не видел свет свободы, принципов и справедливости» ${ }^{18}$. Таким образом, в недрах американского политического истеблишмента была создана ортодоксальная политическая теория гегемонии США, превзошедшая по своей догматичности католическую церковь в прошлом. Не случайно К. Шмит характеризовал идеи мирового господства Вильсона и их теологическое обоснование как «reductio ad absurdum» (лат. - «доведение до абсурда»).

Сразу после окончания Первой мировой войны В. Вильсон создал государственную комиссию по разработке плана расчленения Советской России, в секретных комментариях к которому были «14 пунктов Вильсона», реализация которых, как считали в Вашингтоне, было делом времени. В комментариях американского президента отмечалось, что Россия «слишком велика и гомогенна для нашей безопасности. Я бы хотел видеть Сибирь как отдельное государство, а Европейскую Россию расчленённой на три части» ${ }^{19}$.

Таким образом, должен был окончательно решиться «русский вопрос» посредством расчленения Советской России на отдельные самостоятельные области, подконтрольные Соединённым Штатам ${ }^{20}$. В соответствии с планом Вильсона, предполагалось всю Россию разделить на области, обладающие собственной экономикой, но при этом ни одна область не должна быть достаточно самостоятельной, чтобы образовать сильное государство.

Судьбу России после её расчленения на отдельные квазигосударства можно проиллюстрировать на примере Кубы после её захвата Соединёнными Штатами в 1901 г.

Как известно, оккупационный режим на Кубе сохранялся до тех пор, пока её правительство не приня-

17 Graven A., Jonson W. A Documentary History of the American People. N.Y. 1951, pp. 673-674.

${ }^{18}$ Nicolson H. Peacemaking 1919. Crosset \& Dunlap. N.Y.: 1965, pp. 52-53.

19 Levin Jr., Gordon N. Woodrow Wilson and World Politics. Oxford University Press, Oxford, 1968, p. 219.

20 Документы внешней политики СССР. Т. 1. М., С. 727-728. ло «поправку Платта» в качестве приложения к своей конституции ${ }^{21}$. Важнейшими статьями «поправки Плата» были 1, 2, 3 и 7-я. 1-я статья запрещала Кубе заключение договоров с иностранными государствами; 2-я ограничивала право Кубы брать иностранные займы; 3-я предусматривала право США на интервенцию и лишала Кубу возможности проведения независимой внешней политики; 7-я закрепляла контроль Вашингтона над Кубой, а также обязывала её продавать или сдавать в аренду территорию под склады и базы. Кроме того, все акты законодательного собрания Кубы подлежали утверждению Соединёнными Штатами. Парадоксальной особенностью данной поправки является то, что всякая попытка самоопределения и установление национальной независимости Кубой считалась противоречащей собственной конституции.

Однако мирового господства после Первой мировой войны Соединённым Штатам установить не удалось. Зато доктрина Монро была включена в Устав Лиги Наций в виде Статьи 21, что не только сузило правовые рамки этой организации, исключив из её юрисдикции сферу влияния США, но и привело к подрыву существующего тогда международного права. Недаром К. Шмит заявил, что включение доктрины Монро в Устав Лиги Наций явилось первым поражением Европы от США и началом распада господствующих принципов международного права, исторически сформировавшегося в период между Вестфальским миром в 1648 г. и Конгрессом в Вене в 1815 г. и действующих до сих пор.

После Второй мировой войны продолжилось расширение геополитического пространства Америки, но уже в русле геополитической концепции X. Маккиндера $^{22}$. Согласно его концепции, внутреннее пространство Евразии, называемое им «осевым регионом» мировой политики - «Хартлендом» ${ }^{23}$, и в основном совпадающее с территорией Советского Союза, играет ключевую роль в плане завоевания Америкой мирового господства. Основной принцип его концепции был сформулирован в известной геополитической максиме: «Кто правит Восточной Европой, тот господствует над Хартлендом. Кто правит Хартлендом, тот правит Мировым островом. Кто правит Мировым островом, тот господствует над миром ${ }^{24}$.

21 Нитобург Э.Л. Политика американского империализма на Кубе. 1918-1939. М., 1965.

22 Sloan G.R. Geopolitics in United States Strategic Policy 18901987. Wheatheat Books, Brighton, 1988, p. 113.

23 Термин «Хартленд» в геополитику был введён в 1915 г. британским географом Дж. Фэйгривом, который, как считается, независимо от Маккиндера пришел к ряду основных сходных идей.

24 Mackinder H.J. Democratic Ideas and Realty: a Study in the Politics of Reconstruction. New York. Henry Holt, 1919, p. 186. 


\section{Столкновение цивилизаций /}

Clash of civilizations

Ф. Рузвельт считал, что объединение стран евразийского континента будет представлять опасность для США в экономическом и политическом отношениях. Поэтому американская внешняя политика после Второй мировой войны была направлена на установление американской гегемонии в Европе. Создав НАТО, в нарушение Устава ООН, запрещавшего военные союзы, не имеющие регионального характера, и развивая концепцию доктрины Монро, США подчинили себе в военном и политическом отношениях не только побеждённые Германию, Италию и Японию, но и своих недавних союзников.

После окончания «холодной войны» на смену биполярному устройству мира пришла новая американоцентричная система мирового экономического и политического мироустройства, в котором реализация политики «открытых дверей» сделала глобализацию реальностью 25 .

В настоящее время экспансия США «проявляется в форме «глобальной вовлечённости» Америки в экономическую, политическую и культурную трансформацию мира ${ }^{26}$.

Биполярная конфронтация с СССР дала время Coединённым Штатам сформировать новую структуру международных отношений, создать сеть международных институтов и структур безопасности с подключением к ним других стран. Объединяющее напряжение «холодной войны» способствовало интеграции Запада в его борьбе с лагерем социализма и заложило основы процессов глобализации.

Ослабление экономик европейских стран вследствие Второй мировой войны, приведшее к уменьшению политического веса Европы в международных делах, создало ситуацию, позволившую Соединённым Штатам занять ведущее место в мировой политике, соответствующее их возрастающей мощи и влиянию. Американские политические стратеги полагали, что в условиях послевоенного ослабления Европы США получили уникальную возможность сформировать мировой порядок на принципах, которые бы полностью соответствовали их интересам²7.

Как полагали в политических кругах Америки, наступило время для окончательного отказа от изоляционизма и выхода на опустошенную мировой войной европейскую арену с целью установления там новой системы международных отношений, гарантом которой готовы

25 Cohen W.I. America in the Age of Soviet Power. 1945-1991. Cambridge History of American Foreign Relations. V. 4. Cambridge: Cambridge University Press. 1993, p. 260.

26 Уткин А.И. Сомнения сверхдержавы // США-Канада: экономика, политика, культура. № 11. 1994. С. 3.

27 Maier C.S. The Cold War in Europe: Era of a Divided Continent. Harvard. 1996, p. 171. были стать США. Как подчёркивал 3б. Бжезинский, «предотвратить появление на международной арене доминирующей и антагонистической евразийской державы остаётся центральным моментом в плане способности Америки осуществлять своё мировое лидерство» ${ }^{28}$. «В Евразии первостепенной задачей является создание таких условий, когда ни одно государство или коалиция государств не смогла бы вытеснить США или уменьшить их решающую роль» ${ }^{29}$.

Успех стратегии США в Европе в послевоенный период её восстановления в значительной степени предопределил план Маршалла, являющийся поворотным моментом в истории Америки на её пути к достижению глобального лидерства ${ }^{30}$. План Маршалла, выраженный в форме Программы восстановления Европы (ПВЕ), как представляется в настоящее время, представлял собой системообразующий механизм формирования западного альянса, ведомого США ${ }^{31}$, а Америку превращало в империю нового типа - «империю по приглашению» ${ }^{32}$. Соединённые Штаты оказались в положении приглашенной стороны странами Западной Европы ${ }^{33}$. Объясняется это тем, что в послевоенных условиях США были единственной страной, которая могла оказать экономическую помощь для восстановления европейских стран. Инициировав данное «приглашение» и умело им воспользовавшись, Вашингтон получил взамен согласованную политику западноевропейских государств на многие годы. Более того, здесь прослеживается связующая роль плана Маршалла с генезисом "холодной войны», который заложил основы атлантической солидарности, реализованные в создании блока НАTO ${ }^{34}$.

Однако на пути закрепления глобального доминирования Соединённых Штатов мешало отсутствие общей угрозы, фактора, необходимого для цементирования американского глобализированного мира «открытых дверей». В первое десятилетие после оконча-

\footnotetext{
28 Бжезинский 36. Великая шахматная доска. Господство Америки и его геополитические императивы. М., 1999. С. 12.

29 Brzezinski Z. A Geostrategy for Eurasia // Foreign Affairs. 1997, September/October. p. 52.

30 Kegly C., Wittkopf E.R. American Foreign Policy. Forth Edition. N.Y. St. Martin Press. 1991, p. 152.

31 Дементьев В.Е., Олевская Е.М. «План Маршалла»: взгляд из сегодняшней России. Российский экономический журнал. № 8. 1993. С. 81-86.

32 Maier C.S. The Cold War in Europe: Era of a Divided Continent. Harvard. 1996, p. 32.

33 Там же. С. 152.

34 Secretary of State M.K. Albright. Commencement Address at Harvard University. 1997. Cambridge, Massachusetts // URL: http:// www.usaid.gov/multimedia/video/marchall/albright.html
} 


\section{Международные отношения International Relations}

ния «холодной войны» это обстоятельство разъедало атлантическую солидарность, поскольку без враждебной силы, угрожающей международной безопасности и стабильности, прочность связующих нитей Альянса не может считаться гарантированной ${ }^{35}$

Цели и задачи, заложенные в 1947 г. госсекретарём США Маршаллом, лежат в основе американской внешней политики и в настоящее время. Отличие состоит в том, что после окончания «холодной войны» и образования вакуума влияния в странах постсоветского пространства Соединённые Штаты по-прежнему инициируют предоставление «помощи» данным государствам на условиях их зависимости от Вашингтона. Нынешний американский геополитический экспансионизм 3б. Бжезинский называет «вторжением в геополитический вакуум Евразии» ${ }^{36}$.

Но здесь перед Вашингтоном стоит сложная задача выработки политики в отношении стран, оставшихся за пределами западного мира, хотя и связанного с ним определёнными отношениями. К таким странам относятся, прежде всего, Китай, Россия и Индия. Именно они могут претендовать на собственную значимую роль в мировой политике, которые к тому же являются ядерными державами, что исключает какие-либо силовые варианты действий в отношении их. Поэтому в отношении данных стран Вашингтон применяет стратегии «непрямых действий» и «мягкой силы» с надеждой на то, что в будущем возникнут благоприятные условия для использования технологии «управляемого хаоса» с целью организации «цветных революций» для установления в данных странах проамериканских режимов.

Что касается независимых государств постсоветского пространства, то их руководство строит свою политику на основе использования противоречий интересов великих держав. Это порождает непоследовательность политических курсов данных государств, которые, принимая помощь стран Запада и участвуя в различных международных программах и проектах, не упускают возможности выторговать какие-то привилегии и уступки и со стороны России. Кроме того, руководители данных государств прекрасно понимают, что модернизация своей экономики, силовой и хозяйственной инфраструктур за счёт внешних источников делает эти страны зависимыми от стран-доноров, ухудшение отношений с которыми в случае изменения политического курса может привести к кризису или даже смене режима. Из этого можно сделать вывод о том, что повторение ситуации, которая сложилась в Западной Европе в послевоенный период и которая обеспе-

\footnotetext{
35 Уткин А.И. Американская стратегия для XXI в. М.: С. 17.

36 Brzezinski Z. Out of Control. Collier Books. N.Y.: 1993, pp. 149-166.
}

чила успешную реализацию плана Маршалла, сейчас не возможно.

Вряд ли в XXI в. история сделает исключение и для Соединённых Штатов. На новом витке исторического развития неизбежно возникнут новые центры силы, которые будут противостоять США, пытаясь вытеснить её на вторые роли на международной арене. При этом речь идёт не столько о силовом противостоянии, сколько об объединённом политико-экономическом и культурно-информационном противодействии стран, не желающих испытывать на себе давление США.

Но пока ещё Соединённые Штаты сохраняют позиции мирового лидера. В связи с этим возникает закономерный вопрос: что лежит в основе их более чем векового геополитического господства и как долго оно может продлиться? Почему центры силы, претендующие на глобальную роль, не могут перехватить инициативу у Соединённых Штатов и выйти на лидирующие позиции и что нужно им для этого необходимо сделать?

Причины американской гегемонии можно объяснить с позиций исторической антропологии. Как и во всякой общественной системе, в американском обществе имеет место разделение на две далеко не равные части: основная масса населения создаёт национальные богатства и занята в сфере услуг, а меньшая - работает в области разработки и внедрения инновационных технологий и занята в сфере государственного управления. Таким образом, большинство населения создаёт материальную основу общества, его богатства, а меньшинство - эффективно управляет этими ресурсами и занимается инновациями.

При этом сильной стороной американского общества является совершенство и умелое применение мотивационных компрессоров, которые побуждают людей наращивать потребление товаров и услуг. В США мотивационные потребительские компрессоры развивались в течение всего XX в., оказывая психологическое воздействие на поведение людей, и шли параллельно с экономическим развитием. Здесь следует вспомнить, что первоначальный толчок потребительскому буму дало американское конвейерное производство товаров и соответствующая ему товарная реклама; затем в ход пошла продажа акций и предоставление потребительских кредитов населению, поддерживаемые масс-медийной и брендовой рекламой товаров и услуг. Сейчас наступила эпоха виртуализации мотиваций и потребностей людей с переходом от акцентирования на качестве продуктов к предоставлению комфорта, удовольствий и престижа обладателей какого-либо товара.

В результате экономика, стимулированная спросом, порождённым мотивационными компрессорами, выбрасывает на рынок всё большее количество разнообразных товаров и невероятно разгоняется в своём ро- 


\section{Столкновение цивилизаций /}

Clash of civilizations

сте. Происходит неоправданно быстрая смена товаров внутри каждого бренда в целях стимулирования роста продаж и, следовательно, прибыли корпораций.

В то же время мотивационные компрессоры потребления, наиболее развитые в странах «золотого миллиарда», оказывают влияние на умонастроения у населения стран "третьего мира», порождая потребности не соответствующие уровню экономического развития данных стран. Это ведёт к дестабилизации социально-политической обстановки и неконтролируемой миграции в страны Европы.

Соединённые Штаты будут сохранять мировое лидерство до тех пор, пока интеллектуальная, политическая и бизнес элиты страны будут уделять внимание инновационному развитию. Но как только начнётся затухание инновационной мотивации в американском обществе, и его творческая часть начнёт переходить в группу потребителей материальных благ под действием мотивационных компрессоров потребления, экономическая мощь Соединённых Штатов пойдёт на убыль. Но это относится к далёкой перспективе. А какова нынешняя ситуация в плане наличия претендентов на мировое лидерство и какие требования предъявляются к желающим занять место на мировом Олимпе?

Все критики мировой гегемонии Америки (из России, исламского мира, Китая, Индии и стран Латинской Америки) страдают одним общим недостатком: они ещё не до конца сознают глубинную сущность современного лидерства. США является мировым гегемоном не только и не столько потому, что использует экономическую, военную и культурную силу, а потому что широко используют инновации, трансформируемые в военно-политическую, экономическую и информационную мощь. Всем государствам, претендующим на это звание, следует понять, что стать лидером в современном мире можно только за счёт сочетания двух главных факторов: разработки и широкого внедрения прорывных инноваций и наличия универсальной цивилизационной доктрины государства, которая могла бы стать примером для остального мира. Таким образом, перед мировыми цивилизациями, претендующим на мировое лидерство, встаёт вопрос о наличии собственного цивилизационного проекта и перспективах его признания в мировом сообществе.

Индия предлагает миру философские и культурные ценности индуизма. Однако они не обладают универсальностью и вероятность принятия данного проекта в качестве даже региональной цивилизационной платформы довольно низка.

Латинская Америка, после очередной радикализации общественной жизни, предлагает миру концепцию социализма с латиноамериканским лицом, построенную на сочетании католицизма и революцион- ного марксизма. Как видно, данный проект также имеет региональное значение и не может претендовать на универсальность.

Исламский мир предлагает мировому сообществу духовные и культурные ценности ислама в широком спектре социально-политических реализаций: от его традиционной версии до политического фундаментализма. В настоящее время мы наблюдаем активное продвижение исламского проекта в странах Ближнего Востока, Северной Африки, Европы и в некоторых регионах России. Его реализация возможна в отдалённой исторической перспективе при использовании демографического фактора и религиозного обращения.

Обобщая сказанное, можно констатировать, что миропроекты Индии, Латинской Америки и Исламского мира пока не могут выступать в качестве универсальных цивилизационных основ для значительной части населения Земли, что в настоящее время не даёт возможности данным странам претендовать на роль мировых лидеров.

Что касается Европы, то она после Второй мировой войны всё ещё остаётся в фарватере внешней политики США, является их ближайшим союзником и поэтому не в состоянии выдвинуть свой цивилизационный проект мирового значения, сравнимый с американским проектом либеральной демократии или советским проектом коммунистического Интернационала. Причина в том, что американский цивилизационноый проект основан на европейской философии гуманизма Эпохи просвещения, а чтобы предложить миру что-то принципиально новое, то Европе необходимо будет решительно отказаться от всего философского и культурного наследия прошлых веков, что в настоящее время не представляется возможным.

При этом сильными сторонами американского цивилизационного миропроекта является отсутствие конфессиональной, национальной и культурной привязки, что придаёт ему универсальный характер. Более того, в нём в полной мере используются современные стратегии и технологии глобализации в экономической, информационной и культурной сферах человеческого общества. Это придаёт ему адаптируемость к реальным условиям существования различных социумов.

Россия в ходе социально-политической трансформации решительно отказалась от мирового коммунистического проекта, который имел универсальный характер. Это привело к отказу от роли мирового лидера, что освободило место для США на мировом Олимпе.

Если обратиться к истории, то следует вспомнить, что Советскому Союзу не хватило экономических, идеологических и кадровых ресурсов для того, чтобы удержаться в числе фаворитов в гонке за лидерство двух сверхдержав. Дефицит интеллектуальных ресур- 


\section{Международные отношения International Relations}

сов советского партийного руководства отчётливо проявился в области инноваций, когда были отвергнуты в 1950-х гг. такие прорывные научные направления, как кибернетика, генетика и геополитика. Это положило начало отставанию в вычислительной технике, биотехнологиях и социально-политических науках. Сегодняшние усилия России в области инновационного развития пока не принесли результатов. Поэтому внимание российского руководства сосредоточено не на разработку нового цивилизационного проекта, а на удержание постсоветского пространства в своей зоне влияния и на недопущение проникновения в него внешних сил.

Китай, несмотря на значительные успехи в экономическом развитии и освоении новых технологий, в отношении цивилизационного миропроекта находится в русле Америки. Видимо в Пекине рассчитывают на завоевание гегемонии за счёт перехвата мировых функций США в финансово-экономической и военной сферах, но только после того как американцы начнут сдавать позиции на международной арене. Из-за языкового барьера нам трудно судить о социально-политических процессах в КНР и развитии китайской геополитической мысли. На фоне впечатляющего роста экономической и военной мощи Пекин до сих пор не предложил миру ни одной значимой политической инновации глобального значения. Представляется, что китайское руководство идёт своим путём.

В этом плане, по нашему мнению, представляет интерес рассмотрение вероятных сценариев динамики лидерства на международной арене на среднесрочную перспективу:

1. Сохранение в долгосрочной перспективе Соединёнными Штатами своей лидирующей роли за счёт высокого инновационного потенциала, обеспечивающего их превосходство в экономической, военной и информационной областях, на фоне адаптации цивилизационного проекта либеральной демократии к реалиям современного мира.

2. Прорывное экономическое развитие одного из государств, которое заявит своё право на лидерство сначала посредством применения экономических рычагов, а затем, если возникает такая необходимость, и военным путём, последовательно рас- ширяя свои демографические, экономические и информационные границы и последовательно создавая ареал своего военно-политического и экономического влияния.

3. На роль мировых лидеров начинают претендовать несколько государств и квазигосударственных транснациональных, трансграничных образований, формирующих свои военно-политические и экономические союзы, что приведёт к фрагментации мирового сообщества и соперничеству между собой различных центров силы и влияния.

При этом все три сценария нельзя рассматривать как антагонистические альтернативы. Их осуществление зависит от геополитической динамики всего мирового сообщества. Развитие по первому сценарию возможно при постепенном социальном, экономическом и инновационном развитии ведущих субъектов международного сообщества, что создаст благоприятные условия для сохранения лидирующих позиций Соединёнными Штатами.

Второй сценарий развития возможен при прорывном экономическом и инновационном развитии хотя бы одного из претендентов на мировое лидерство, который силовым путём изменит геополитический баланс в свою пользу.

Третий сценарий может осуществиться при успешном экономическом и инновационном развитии сразу двух и более государств, фрагментирующих международное сообщество на конкурирующие блоки и коалиции.

В качестве альтернативы вышеизложенным сценариям можно предположить ситуацию, когда на роль мирового гегемона станет претендовать не одно или несколько государств, а некая транснациональная организация или некое трансграничное сетевое сообщество, не имеющее государственной привязки и существующее в виртуальном пространстве глобальных коммуникаций, но способное управлять мотивациями социумов, что и было недавно опробовано в ходе революционных событий так называемой «арабской весны». Однако для появления такого «виртуального гегемона» потребуется довольно продолжительный период времени, что выходит за рамки рассматриваемого прогноза.

\section{Источники:}

1. Бжезинский 3б. Великая шахматная доска. Господство Америки и его геополитические императивы. М., 1999. C. 13.

2. Давыдов Ю.П. Расширение зоны ответственности атлантического мира // США - Канада: экономика, политика, культура. № 3. 2000. С. 17.

3. Carl Schmitt. Der Nomos der Erde im Volkerrecht des jus publicum Europaeum. Cologne, 1950.

4. Lowell L.A. The Colonial Expansion of the United States // Atlantic Monthly, LXXXII, 1999, pp. 145-154. 
5. Hofstadter R. Social Darvinism in American Thought. Baecon Press, Boston, 1983, pp. 187-188.

6. Preface by Hart A.B. to the Works of Theodore Roosevelt. Charles Scribner's Sons, N.Y., 1926.

7. Дипломатический словарь. Т. 1. Госполитиздат. - М., 1948. - С. 272.

8. Levin Jr., Gordon N. Woodrow Wilson and World Politics. Oxford University Press, Oxford, 1968, p. 186.

9. Williams A. The Shaping of American Diplomacy. Rand NcNally Company, Chicago, 1972, p. 423.

10. Поздняков Э.А. Геополитика. Изд. гр. «Прогресс-Культура». - М.: 1995. С. 36.

11. Adams B. The New Industrial Revolution. Atlantic Monthly, LXXXVII, 1901, p. 165.

12. George D.L. The Truth About Peace Treaties. Vol. 1, London, 1938, pp. 223-225; Bailey T.A. A Diplomatic History of the American People. Prentice Hall Inc., Englewood Cliffs, 1980, p. 608.

13. Graven A., Jonson W. A Documentary History of the American People. N.Y. 1951, pp. 673-674.

14. Nicolson H. Peacemaking 1919. Crosset \& Dunlap. N.Y.: 1965, pp. 52-53.

15. Levin Jr., Gordon N. Woodrow Wilson and World Politics. Oxford University Press, Oxford, 1968, p. 219.

16. Документы внешней политики СССР. Т. 1. - М.: С. 727-728.

17. Нитобург Э.Л. Политика американского империализма на Кубе. 1918-1939. - М., 1965.

18. Sloan G.R. Geopolitics in United States Strategic Policy 1890-1987. Wheatheat Books, Brighton, 1988, p. 113.

19. Mackinder H.J. Democratic Ideas and Realty: a Study in the Politics of Reconstruction. New York. Henry Holt, 1919, p. 186.

20. Cohen W.I. America in the Age of Soviet Power. 1945-1991. Cambridge History of American Foreign Relations. V. 4. Cambridge: Cambridge University Press. 1993, p. 260.

21. Уткин А.И. Сомнения сверхдержавы // США-Канада: экономика, политика, культура. № 11, 1994, с.3.

22. Maier C.S. The Cold War in Europe: Era of a Divided Continent. Harvard. 1996, p. 171.

23. Brzezinski Z. A Geostrategy for Eurasia // Foreign Affairs. 1997, September/October. p/ 52.

24. Kegly C., Wittkopf E.R. American Foreign Policy. Forth Edition. N.Y. St. Martin Press. 1991, p. 152.

25. Дементьев В.Е., Олевская Е.М. «План Маршалла»: взгляд из сегодняшней России. Российский экономический журнал. - № 8. - 1993. - С. 81-86.

26. Maier C.S. The Cold War in Europe: Era of a Divided Continent. Harvard. 1996, p. 32.

27. Secretary of State M.K. Albright. Commencement Address at Harvard University. 1997. Cambridge, Massachusetts // http://www.usaid.gov/multimedia/video/marchall/albright.html

28. Уткин А.И. Американская стратегия для XXI в. - М.: С. 17.

29. Brzezinski Z. Out of Control. Collier Books. N.Y.: 1993, pp. 149-166.

\section{References (transliteration):}

1. Bzhezinskii Zb. Velikaya shahmatnaya doska. Gospodstvo Ameriki i ego geopoliticheskie imperativy. - M., 1999. - S. 13.

2. Davydov Yu.P. Rasshirenie zony otvetstvennosti atlanticheskogo mira // SShA - Kanada: ekonomika, politika, kul'tura. № 3. 2000. - s. 17.

3. Diplomaticheskii slovar'. T. 1. Gospolitizdat. - M.: 1948. - S. 272.

4. Dokumenty vneshnei politiki SSSR. T. 1. - M.: - S. 727-728.

5. Nitoburg E.L. Politika amerikanskogo imperializma na Kube. 1918-1939. - M., 1965.

6. Dement'ev V.E., Olevskaya E.M. «Plan Marshalla»: vzglyad iz segodnyashnei Rossii. Rossiiskii ekonomicheskii zhurnal. № 8. - 1993. - S. 81-86.

7. Utkin A.I. Amerikanskaya strategiya dlya XXI v. - M.: - S. 17. 